\title{
РОЗВИТОК ОБШИРНОГО ІНФАРКТУ МІОКАРДА ВНАСЛІДОК МНОЖИННИХ АНЕВРИЗМ КОРОНАРНИХ АРТЕРІЙ
}

\author{
๑М. І. Швед, Н. М. Ковбаса, Н. І. Ярема, Т. О. Добрянський, \\ І. М. Герасимець, О. А. Прокопович
}

Тернопільський національний медичний університет імені І. Я. Горбачевського МОЗ України

РЕЗЮМЕ. Широкий діапазон коливань поширеності аневризматичної хвороби коронарних судин (від 0,02 до 1,4 \%) пов'язують не лише з рідкісністю патології, а й з неспецифічністю клінічних проявів та труднощами візуалізаційної діагностики.

Мета - аналіз сучасних підходів до діагностики та лікування пацієнтів із множинними аневризмами коронарних судин, ускладнених гострим інфарктом міокарда, та розбір власного клінічного випадку для оцінки клінічної адекватності запропонованого діагностично-лікувального алгоритму.

Матеріал і методи. Використали системний аналіз, бібліосемантику та аналіз випадку захворювання на множинні аневризмами коронарних судин.

Результати. Наведений клінічний випадок характеризується типовою клінічною симптоматикою гострого коронарного синдрому (ГКС), причиною якого стали множинні аневризми коронарних артерій. Ідентифікували етіологію ГКС шляхом проведення контрастної коронароангіографії. Згідно із запропонованим діагностично-лікувальним алгоритмом ведення таких хворих пацієнту проведено аортокоронарне шунтування і призначено подвійну антиагрегантну та статинотерапію, що дало стабільний клінічний ефект.

Висновки. Різноманітність клінічних проявів аневризматичної хвороби серця зумовлює суттєві діагностичні труднощі даної хвороби і обґрунтовує необхідність використання різноманітних діагностичних візуалізаційних підходів (коронаровентрикулографія, комп'ютерна томографія, аортографія), а безпосередня тактика лікування хворих на аневризми/ектазії коронарних артерій повинна бути індивідуалізована на основі запропонованого діагностично-лікувального алгоритму.

КЛючОВІ СлОВА: аневризма коронарної артерії; діагностично-лікувальний алгоритм.

Вступ. Аневризматична хвороба коронарних артерій охоплює поняття аневризм коронарних судин та їх ектазії [2]. Аневризми коронарних артерій (AKA) - рідкісна патологія коронарних судин, за якої спостерігається локальне розширення просвіту коронарної артерії більш ніж у 1,5 раза, порівняно з сусідніми нормальними сегментами. 3 іншого боку, ектазії коронарних артерій виглядають як дифузні дилатації судин, де довжина розширеного сегмента перевищує 50 \% їх діаметра [1]. АКА поділяють на поперечні, якщо поперечний діаметр перевищує поздовжній розмір, та на веретеноподібні аневризми в протилежному випадку [2]. Залежно від цілісності стінки судини, аневризми класифікують як істинні (зі збереженням тришарової структури стінки судини) та псевдоаневризми, коли ділянка розширення судини складається 3 одинарного або двох шарів судинної стінки. Зазвичай псевдоаневризми виникають як наслідок тупої травми грудної клітки або коронарного втручання, тоді як справжня артеріальна аневризма це веретеноподібна або поперечна дилатація артерії зі збереженням усіх трьох шарів оболонки судини. Описано гігантські коронарні аневризми, діаметр яких перевищує 8 мм, їх поширеність становить $0,02 \%$ серед всіх аневризм $[1,3]$.

Поширеність аневризматичної хвороби коронарних судин, згідно з результатами ангіографії, коливається від 0,2 до 10 \% і вказаний широкий діапазон пов'язують із використанням різноманітних ангіографічних критеріїв для визначення аневризм та ектазій коронарних судин [3]. У найбільшому посмертному секційному дослідженні встановлено поширеність АКА на рівні лише 1,4%, причому захворюваність вища у чоловіків, ніж у жінок (2,2% проти 0,5 \%).

Коронарні ектазії зустрічаються частіше, ніж AKA [4]. Обидва стани можуть спостерігатись у будь-якому віці. Права коронарна артерія $\epsilon$ найчастішим місцем локалізації аневризм чи ектазії $(40,4 \%)$, далі передня міжшлуночкова артерія $(32,3 \%)$, огинаюча артерія (23,4 \%) і, рідко, стовбур лівої коронарної артерії (3,5 \%). Аневризматична хвороба коронарних судин атеросклеротичного чи запального ґенезу зазвичай множинна і охоплює більше однієї артерії, тоді як уроджені, травматичні чи розшаровуючі аневризми, як правило, поодинокі [3].

Виявлено суттєво нижчу поширеність АКА серед населення Азії, порівняно з Північною Америкою та Європою, що пов'язують із генетичними та екологічними впливами. На противагу цьому, АKА через хворобу Кавасакі $\epsilon$ більш поширеними у пацієнтів азіатської етнічної належності (10,3%), ніж у кавказьких (6,9 \%) або африканських етнічних групах (1,2 \%) [1-3]. 
Огляди літератури, оригінальні дослідження, погляд на проблему, випадок з практики, короткі повідомлення

Найчастішою причиною виникнення AKA $\epsilon$ атеросклероз, який пов'язаний з половиною всіх діагностованих випадків коронарних аневризм у дорослих [5]. Гістологічне дослідження атеросклеротичних АКА встановило гіалінізацію та відкладання ліпідів, що призводить до порушення інтими та медіального шару стінки судини, руйнування м'язових еластичних компонентів. Такі особливості послаблюють стінку судини і зменшують її еластичність, знижуючи толерантність до внутрішньолюмінального тиску, тим самим сприяючи подальшій дилатації та утворенню аневризми. Тривале трансмуральне запалення, що характерне для ішемічної хвороби, ще більше сприяє цьому процесу ослаблення стінки судин. Окремі автори припускають, що хронічне надмірне стимулювання судинорозширювального оксиду азоту та локальні механічні напруги від стенозів можуть сприяти ослабленню медіальної стінки коронарної артерії $[1,6]$.

На підтримку концепції розвитку аневризм коронарних судин у хворих на ішемічну хворобу серця проведено декілька пов'язаних досліджень геному (genome-wideassociationstudy - GWAS), в яких виявили асоціацію варіантів на хромосомі 9p21.3 з аневризмами коронарних судин. Також цей локус пов'язаний з підвищеним ризиком розвитку різних інших захворювань, включаючи несприятливе ремоделювання черевної аорти та підвищення ризику розвитку внутрішньочерепних аневризм $[7,8]$.

До інших причин аневризматичної хвороби коронарних судин належать запальні артеріальні захворювання (хвороба Кавасакі, вузликовий поліартеріїт, артеріїт Такаясу, хвороба Бехчета, сифіліс), хвороби сполучної тканини (системний червоний вовчак, ревматоїдний артрит, анкілозуючий спондиліт, системна склеродермія), спадкові дефекти колагену (синдром Марфана, синдром Елера-Данлоса), вроджені аномалії коронарних артерій (ARCAPA та ALCAPA або Bland-WhiteGarland-синдром), фістули коронарних судин (як правило, лівої коронарної), черезшкірне коронарне втручання (балонна ангіопластика, стентування, артеректомія), грибкова інфекція, інтоксикація кокаїном, травма та первинний гіперальдостеронізм. Загалом атеросклероз є найпоширенішою причиною у дорослих, а хвороба Кавасакі - найпоширеніша причина у дітей[3].

у більшості випадків аневризматична хвороба коронарних судин перебігає безсимптомно, а коронарні відхилення виявляють випадково під час комп'ютерної томографії, ангіографії або некропсії. Найчастіше клінічні прояви АКА подібні до тих, що спостерігаються при IXС. Часта знахідка наявність тромбів всередині аневризми. Повіль- ний потік крові та її «завихрення» в ділянці дилатації стінки судини зумовлює утворення тромбів 3 подальшою дистальною емболізацією, внаслідок чого виникають ішемія міокарда, стенокардія та/ або інфаркт і раптова смерть.

Розрив аневризми є рідкісним явищем, проте потенційним небезпечним ускладненням АKА. У пацієнтів з гігантськими аневризмами їх необхідно диференціювати із синдромом верхньої порожнистої вени або з пухлинами середостіння, які часто неправильно інтерпретують як серцеву пухлину, кісту або іншу неоплазію.

Вищенаведені факти свідчать про різноманітність клінічних проявів даного патологічного стану, що зумовлює необхідність використання різноманітних діагностичних візуалізаційних підходів для правильної діагностики. Це спонукало нас поділитися результатами власного клінічного спостереження особливостей діагностики даної патології та оцінити ефект від хірургічного лікування при множинних аневризмах коронарних артерій.

Мета - аналіз сучасних підходів до діагностики й лікування пацієнтів із множинними аневризмами коронарних судин, ускладненими гострим інфарктом міокарда, та розбір власного клінічного випадку для оцінки клінічної адекватності запропонованого діагностично-лікувального алгоритму.

Матеріал і методи дослідження. Системний аналіз, бібліосемантика та аналіз випадку захворювання конкретного пацієнта з множинними аневризмами коронарних судин. Пошук джерел здійснювався за допомогою науково-статистичної бази даних медичної інформації PubMed-NCBI.

Опис клінічного випадку. 25.11.19 року в палату інтенсивної терапії кардіологічного відділення Тернопільської університетської лікарні госпіталізовано хворого Р., 51 рік, зі скаргами на пекучий, стискаючий біль за грудниною, виражену загальну слабкість. 3 анамнезу відомо, що біль відмітив 23.11.19 року о 20:00, який рецидивував о 0:40 24.11.19 року. Напередодні грав у футбол. За медичною допомогою звернувся у районну лікарню за місцем проживання, діагностовано гострий коронарний синдром з елевацією сегмента ST на електрокардіограмі. Бригадою екстреної медичної допомоги хворий доставлений у ТУЛ. Понад 15 років хворіє на артеріальну гіпертензію II ступеня, антигіпертензивних засобів систематично не вживав.

При госпіталізації шкірні покриви блідо-рожеві, чисті, помірно вологі, теплі на дотик. Температура тіла від $36,6^{\circ} \mathrm{C}$. Пульс - 78 на хвилину, ритмічний. На кардіомоніторі синусовий ритм. Артеріальний тиск - 150/100 - 160/110 мм рт. ст. Аускультативно діяльність серця ритмічна, тони ослаблені, систолічний шум над верхівкою, ак- 
Огляди літератури, оригінальні дослідження, погляд на проблему, випадок з практики, короткі повідомлення цент II тону над аортою. Дихання самостійне, з частотою 16 на хвилину, сатурація кисню за даними пульсоксиметрії - 96 \% (без інгаляції кисню). Над легенями вислуховується дихання з жорстким відтінком. Живіт симетричний, м'який, не болючий. Відділи товстого кишечника без паль-

паторних змін. Печінка +3 см нижче реберної дуги. Периферійні набряки відсутні.

На електрокардіограмі (ЕКГ) при поступленні (рис. 1) діагностовано елевацію сегмента ST та негативні зубці T(-) у V1-V4, Dorsalis, Anterior, ознаки гіпертрофії лівого шлуночка.
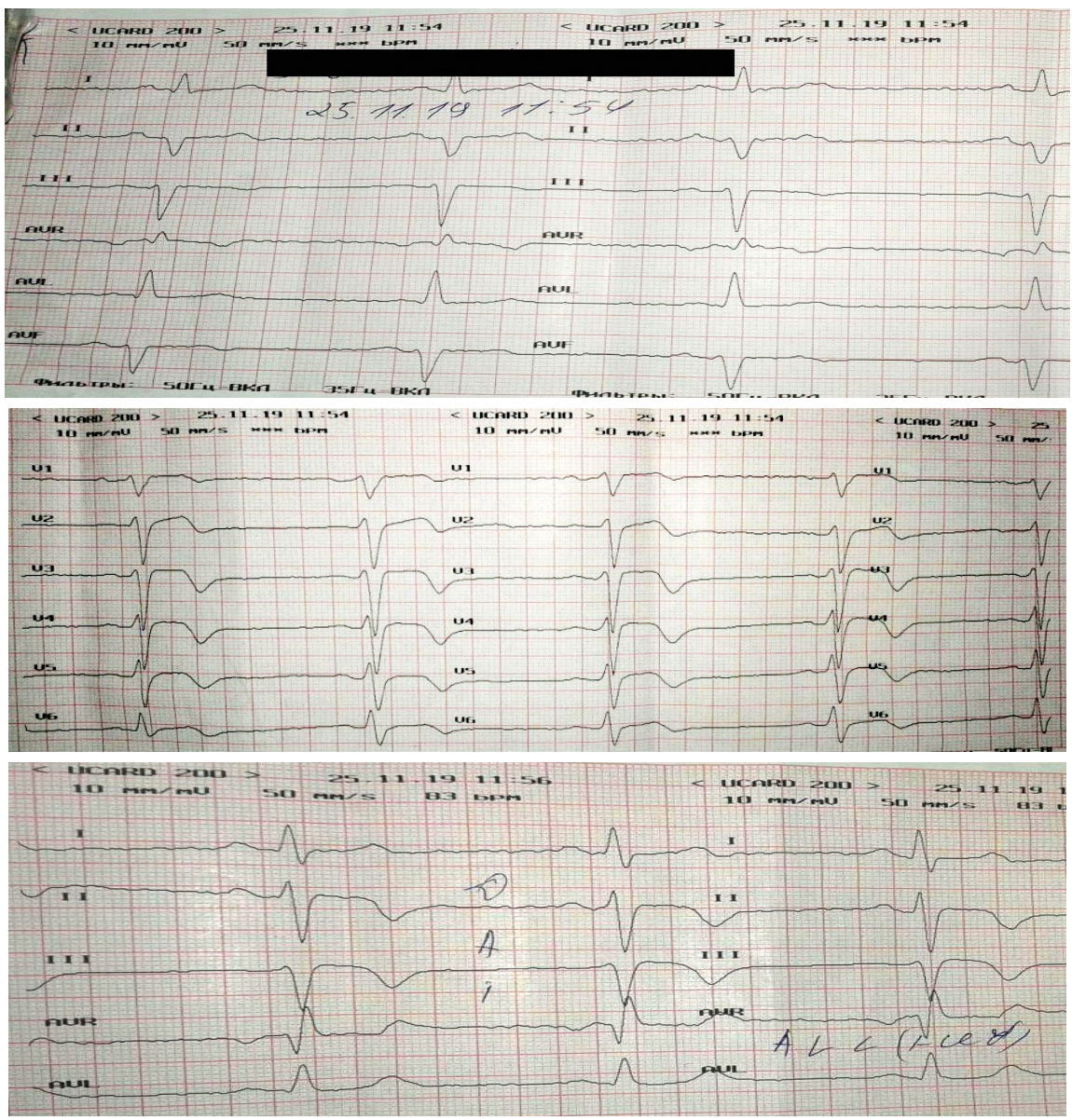

Рис. 1. Електрокардіограма пацієнта Р., 25.11.2019 р.

За результатами лабораторних обстежень відмічено значне підвищення рівня МВ-фракції креатинфосфокінази (МВ-КФК) - 71,3 Од/л (норма <25,0 Од/л), тропоніну Т - 1585 нг/мл (норма 12,7-24,9 нг/мл), аспартатамінострансферази 131,9 Од/л, гіперхолестеринемію (6,47 ммоль/л), гіпертригліцеридемію (3,16 ммоль/л). Інших відхилень у лабораторних показниках не виявлено.

За даними ехокардіоскопії (ЕхоКС) 25.11.2019 р.аорта - 3,8 см, аортальний, мітральний та трикуспідальний клапани без структурно-функціональних змін; кінцево-діастолічний розмір лівого шлуночка - 4,0 см, товщина міжшлуночкової перегородки 1,20-1,25 см, задньої стінки лівого шлуночка 1,10-1,15 см, з незначним гіпокінезом передньосептальної ділянки лівого шлуночка, бокової стінки на базальному та середньому рівнях; фракція викиду 56 \%. Ехокардіографічно коронарні артерії не досліджувались у зв'язку з недостатньою роздільною здатністю апарату.

Враховуючи виражений рецидивний больовий синдром, інфарктоподібні зміни ЕКГ та високий рівень маркерів некрозу міокарда хворому ургентно проведено коронарографію та виявлено аневризматично розширений стовбур лівої коронарної артерії, невелику мішкоподібну аневризму в 11 сегменті та веретеноподібну аневризму в 13 сегменті; у передній міжшлуночковій артерії в 6-7 сегменті веретеноподібна аневризма великих розмірів зі стазом контрасту в порожнині та локально; у правій коронарній судині стеноз до $50 \%$ та аневризма в 1 сегменті (рис. 2).

3 метою виключення запального ґенезу аневризм коронарних артерій хворому взято кров на 
Огляди літератури, оригінальні дослідження, погляд на проблему, випадок з практики, короткі повідомлення
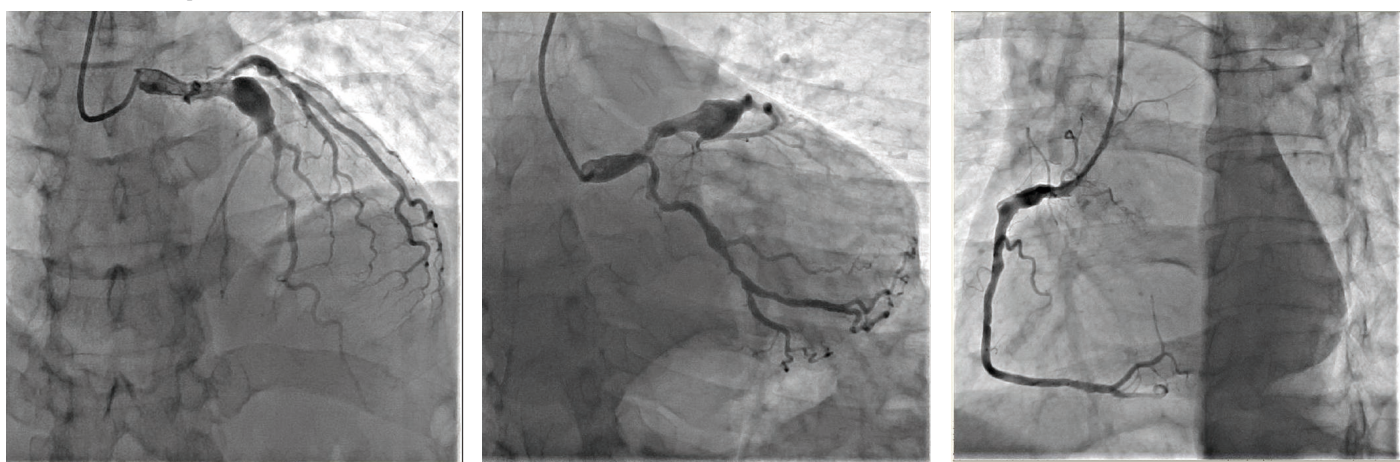

Рис. 2. Результати коронароангіографії пацієнта Р.

визначення антистрептолізину О (113 Од/л, норма негативний - 200 Од/л), ревматоїдного фактора (9,2 Од/л, норма до 14,0 Од/л), С-реактивного протеїну (4,67 мг/л, норма < 5,0 мг/л). Результати досліджень виявились в межах референтних значень.
Також пацієнту проведено аортографію (рис. 3) та комп'ютерну томографію головного мозку з контрастуванням (рис. 4), за результатами яких вогнищевих і судинних змін головного мозку та даних за аневризматичне ураження аорти не виявлено.
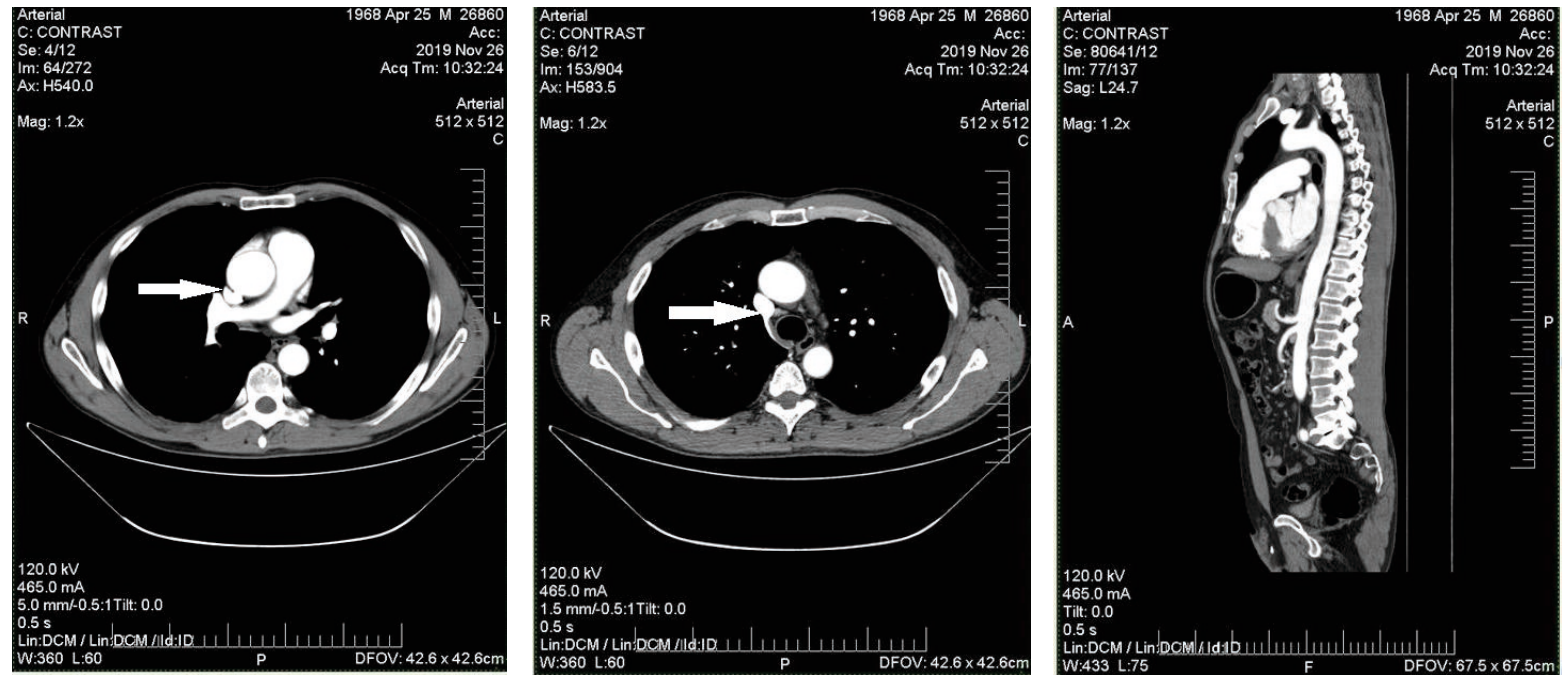

Рис. 3. Аортографія пацієнта Р. (стрілкою вказано аневризму лівої коронарної артерії).
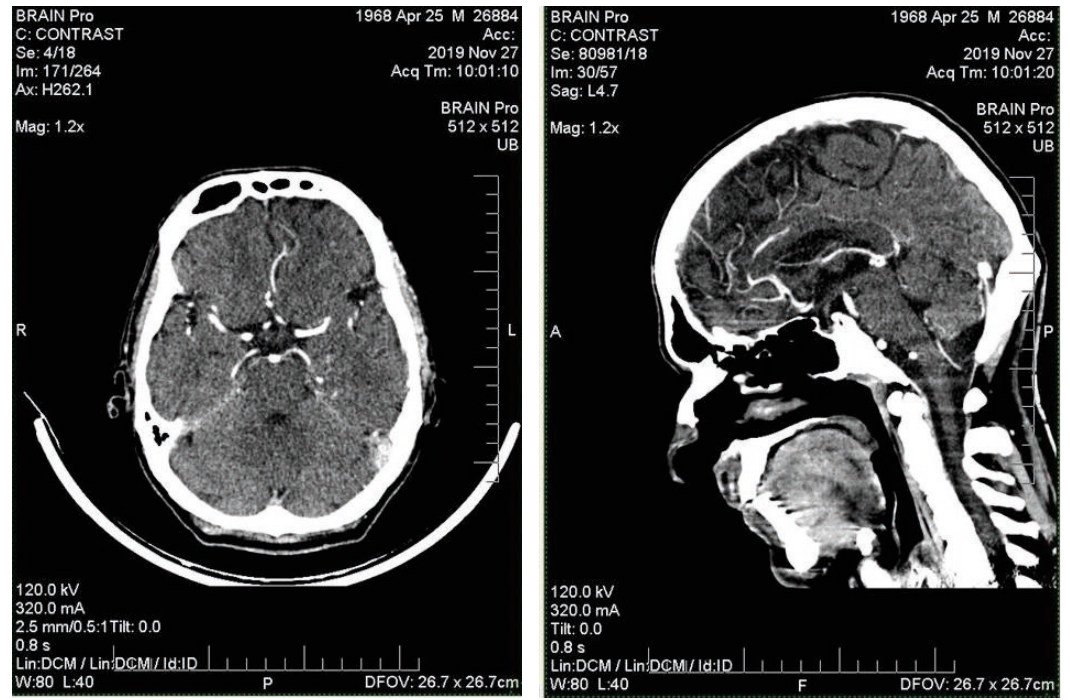

Рис. 4. Комп'ютерна томографія головного мозку пацієнта Р. 
Огляди літератури, оригінальні дослідження, поглядн на

Враховуючи вищеописані клінічні та лабораторно-інструментальні дані пацієнту був встановлений робочий діагноз: IXC: гострий поширений, без зубця Q, передньо-перегородково-верхівково-боковий інфаркт міокарда лівого шлуночка (24.11.2019). Ургентна коронароангіографія (25.11.2019) - множинні аневризми коронарних артерій. CH II Killip.

Відповідно до діагнозу призначено лікування: гепарин по 2500 ОД 4 рази на добу підшкірно; антитромбоцитарну (плавикс 75 мг на добу, аспірин кардіо 100 мг 1 раз на добу)) та антиангінальну терапію (бісопролол в дозі 2,5 мг/добу); статини (розувастатин в дозі 40 мг на добу); гіпотензивну терапію (периндоприл в дозі 8 мг на добу) і рекомендовано консультацію кардіохірурга для вирішення питання щодо оперативного втручання.

11.12.2019 року в умовах штучного кровообігу пацієнту проведено аортокоронарне шунтування передньої міжшлуночкової артерії та огинаючої гілки лівої коронарної артерії. Післяопераційний період перебігав без особливостей, ангінозний синдром не рецидивував. При виписуванні (21.12.2019) хворому рекомендовано антитробоцитарну терапію (аспірин 100 мг 1 раз на добу та клопідогрель 75 мг 1 раз на добу постійно), непрямі або оральні антикоагулянтни (варфарин під контролем МНВ в межах 2,0-3,0 або ксарелто 20 мг на добу), гіпотензивну терапію (периндо- роблему, випадок з практики, короткі повідомлення прил 8 мг на добу), статини (розувастатин в дозі 40 мг на добу).

Загалом можна зробити висновок, що вибір методу лікування як у симптомних, так і в безсимптомних хворих на аневризматичну хворобу коронарних артерій $є$ остаточно не визначеним, оскільки більшість клінічних рекомендацій ґрунтуються на серії клінічних випадків через відсутність масштабних рандомізованих досліджень. Враховуючи вищенаведені обставини, доцільно використати стратегію індивідуалізованого ведення таких хворих (рис. 5), засновану на діагностично-лікувальному алгоритмі, при якому враховують розташування та морфологію аневризм/ектазій, наявність/ відсутність супутнього коронарного стенозу, стенокардії напруги чи гострого коронарного синдрому та супутньої патології [1, 2].

Згідно з наведеними рекомендаціями, при асимптомному перебігу необхідно оцінити ризик розриву чи емболізації аневризм, їх морфологію та кількість. Оскільки АКА часто асоціюються з IXC, то модифікація способу життя та прийом подвійної антитромбоцитарної терапії для таких хворих $\epsilon$ обов'язковим. При множинних аневризмах рекомендовано розглянути додаткове призначення антикоагулянтів (варфарину або нових оральних антикоагулянів) до аспірину з клопідогрелем.

Якщо аневризматична хвороба серця $є$ симптомною та проявляється стабільною стенокардією

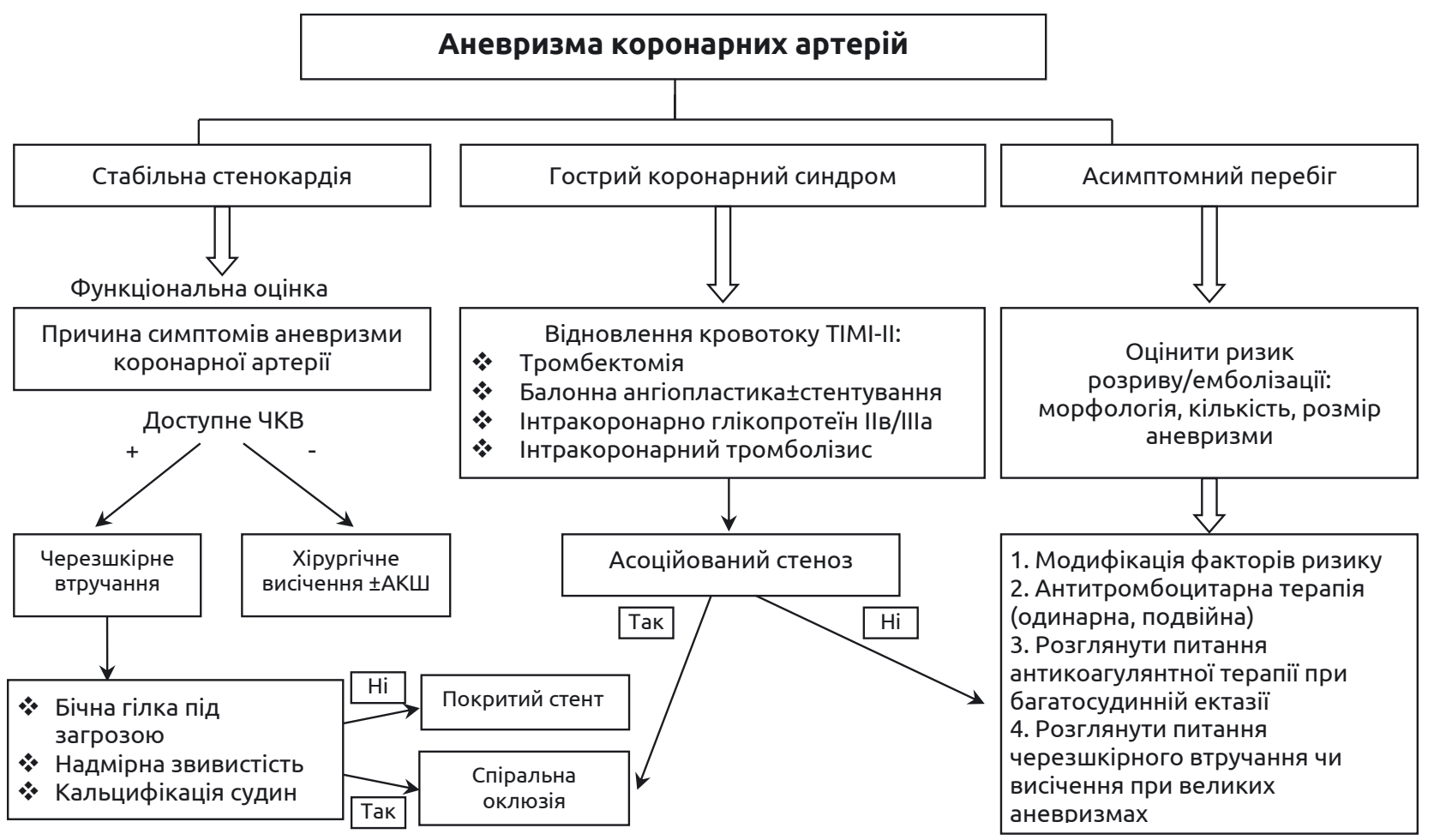

Рис. 5. Алгоритм ведення хворого з аневризмами/ектазіями коронарних артерій (Abou Sherifetal., 2017; Kawsara A. Et al., 2018). 
Огляди літератури, оригінальні дослідження, погляд на проблему, випадок з практики, короткі повідомлення напруги, то перкутанне коронарне втручання, зокрема імплантація покритих стентів, показана при малих або веретеноподібних псевдоаневризмах, що не локалізуються у діагональних гілках. При розташуванні таких аневризм у діагональних гілках, при надмірній звивистості чи кальцифікації коронарних судин методом вибору є емболізація. Великі (понад 20 мм в опорному діаметрі судини) та множинні аневризми, аневризми стовбура лівої коронарної артерії, аневризми венозного трансплантата потребують хірургічної ексцизії з наступним аортокоронарним шунтуванням.

Тромбектомія, балонна ангіопластика та стентування, інтракоронарне введення глікопротеїнових рецепторів ІІв/ІІІа чи тромболітиків $\epsilon$ стратегією лікування хворих з АКА, в яких розвинувся гострий коронарний синдром.

Дотримання рекомендацій вищенаведеного діагностично-лікувального алгоритму в описаному нами клінічному спостереженні дозволило досягнути сприятливого клінічного результату.

Висновки. 1. Різноманітність клінічних проявів аневризматичної хвороби серця: безсимптомний перебіг, стабільна стенокардія напруги чи гострий коронарний синдром, симптоми стискання через гігантські розміри, зумовлює суттєві діагностичні труднощі при цій хворобі й обґрунтовує необхідність використання різноманітних діагностичних візуалізаційних підходів, таких як коронаровентрикулографія, комп'ютерна томографія, аортографія.

2. Сучасні рекомендації щодо діагностики та лікування аневризм коронарних судин в основному базуються на даних серії клінічних випадків, тому на сьогодні назріла необхідність проведення рандомізованих плацебо-контрольованих досліджень для ідентифікації оптимальної стратегії ведення таких пацієнтів, доцільно також організувати національні реєстри для збору епідеміологічних даних та визначення адекватності лікувального процесу.

3. Безпосередня тактика лікування хворих на аневризми/ектазії коронарних артерій повинна бути індивідуалізована на основі діагностично-лікувального алгоритму з урахуванням розташування та морфології аневризм/псевдоаневризм та наявності/відсутності супутнього коронарного стенозу, стенокардії напруги чи гострого коронарного синдрому та супутньої патології.

\section{ЛІТЕРАТУРА}

1. Coronary artery aneurysms: A review of the epidemiology, pathophysiology, diagnosis, and treatment / S. A. Sherif, O. O. Tok, Ö. Tasköylü [et al.] // Front. Cardiovasc. Medicine. - 2017. - Vol. 12. - P. 1-12. DOI: $10.3389 / f c v m .2017 .00024$.

2. Management of coronary artery aneurysms / A. Kawsara, I. J. Núñez Gil, F. Alqahtani [et al.] // JACC: Cardiovascular Interventions. - 2018. - Vol. 11 (13). - P. 12111223. DOI: 10.1016/j.jcin.2018.02.041.

3. ElGuindy M. S. Aneurysmal coronary artery disease: An overview / M. S. ElGuindy, A. M. ElGuindy // Global. Cardiology Science Practice. - 2017. - Vol. 2017. - No 3. P. 1-17.

4. Hartnell G. G. Coronary artery ectasia. Its prevalence and clinical significance in 4993 patients / G. G. Hartnell, B. M. Parnell, R. B. Pridie // British Heart Journal. 1985. -

\section{REFERENCES}

1. Sherif, S.A., Tok, O.O., Tasköylü, Ö., Goktekin, O., \& Kilic, I.D. (2017). Coronary artery aneurysms: A review of the epidemiology, pathophysiology, diagnosis, and treatment. Front Cardiovasc. Medicine, 12, 1-12. DOI:10.3389/fcvm.2017.00024.

2. Kawsara, A., Núñez Gil, I.J., Alqahtani, F., Moreland, J., Rihal, C.S., \& Alkhouli, M. (2018). Management of coronary artery aneurysms. JACC: Cardiovascular Interventions, 11 (13), 1211-1223. doi: 10.1016/j.jcin.2018.02.041.

3. ElGuindy, M., \& ElGuindy, A. (2018). Aneurysmal coronary artery disease: An overview. Global Cardiology Scienceand Practice, 2017, 3, 1-17.

4. Hartnell, G., Parnell, B., \& Pridie, R. (1985). Coronary

Vol. 54 (4). - P. 392-395. Doi: 10.1136/hrt.54.4.392.

5. Cohen P. Coronary artery aneurysms: a review of the natural history, pathophysiology, and management / P. Cohen, P. T. O'Gara // Cardiol. Rev. - 2008. - Vol. 16 (6). P. 301-304. DOI: 10.1097/CRD.0b013e3181852659.

6. Shved M. Coronary artery aneurysm: a review / M. Shved, M. Lesch // Prog. Cardiovasc. Dis. - 1997. Vol. 40 (1). - P. 77-84. DOI:10.1016/s0033-0620(97)80024-2.

7. The same sequence variant on 9p21 associates with myocardial infarction, abdominal aortic aneurysm and intracranial aneurysm / A. Helgadottir, G. Thorleifsson, K. Magnusson [et al.] // Nature Genetics. - 2008. - Vol. 40 (2). P. 217-224. DOI: 10.1038/ng.72.

8. Ozaki K. Molecular genetics of coronary artery disease / K. Ozaki, T. Tanaka // Journal of Human Genetics. 2015. - Vol. 61 (1). - P. 71-77. DOI:10.1038/jhg.2015.70.

artery ectasia.Its prevalence and clinical significance in 4993 patients. Heart, 54 (4), 392-395.

5. Cohen, P., \& O'Gara, P. (2008). Coronary artery aneurysms. Cardiology in Review, 16 (6), 301-304.

6. Shved, M., \& Lesch, M. (1997). Coronary artery aneurysm: A review. Progressin Cardiovascular Diseases, 40 (1), 77-84.

7. Helgadottir, A., Thorleifsson, G., Magnusson, K., Grétarsdottir, S., Steinthorsdottir, V., Manolescu, ..., \& Stefansson, K. (2008). The same sequence variant on 9p21 associates with myocardial infarction, abdominal aortic aneurysm and intracranial aneurysm. Nature Genetics, 40 (2), 217-224.

8. Ozaki, K., \& Tanaka, T. (2015). Molecular genetics of coronary artery disease. Journal of Human Genetics, 61 (1), 71-77. 
Огляди літератури, оригінальні дослідження, погляд на проблему, випадок з практики, короткі повідомлення

РАЗВИТИЕ ОБШИРНОГО ИНФАРКТА МИОКАРДА ВСЛЕДСТВИЕ МНОЖЕСТВЕННЫХ

\title{
АНЕВРИЗМ КОРОНАРНЫХ АРТЕРИЙ
}

\author{
๑Н. И. Швед, Н. М. Ковбаса, Н. И. Ярема, Т. А. Добрянский, \\ И. М. Герасимец, А. А. Прокопович
}

Тернопольский национальный медицинский университет имени И. Я. Горбачевского МОз Украины

PEзЮМЕ. Широкий диапазон колебаний распространенности аневризматической болезни коронарних сосудов (от 0,02 до 1,4 \%) связывают не только с редкостю патологии, но и с неспецифичностю клинических проявлений и трудностями визуализационной диагностики.

Цель - анализ современных подходов к диагностике и лечению пациентов с множественными аневризмами коронарних сосудов, осложненными острым инфарктом миокарда, разбор собственного клинического случая для оценки клинической адекватности предложенного диагностично-терапевтического алгоритма.

Материал и методы. Использовали системный анализ, библиосемантику и анализ случая болезни множественной аневризмой коронарних сосудов.

Результаты. Представленный клинический случай характеризуется типичной клинической симптоматикой острого коронарного синдрома (ОКС), причиной которого стали множественные аневризмы коронарних артерий. Идентифицировали этиологию ОКС путем проведения контрастной коронароангиографии. Согласно с предложенным диагностически-терапевтическим алгоритмом ведения таких больных пациенту проведено аортокоронарное шунтирование и назначена двойная антиагрегантная и статинотерапия, что дало стабильный клинический эффект.

Выводы. Разнообразие клинических проявлений аневризматической болезни сердца обуславливает существенные диагностические трудности данной патологии и обосновывает необходимость использования разнообразных диагностических визуализационных подходов (коронаровентрикулография, компьютерная томография, аортография), а непосредственная тактика лечения больных аневризмами/ектазиями коронарных артерий должна быть индивидуализирована на основании предложенного диагностично-терапевтического алгоритма.

КЛЮчЕВЫЕ СЛОВА: аневризма коронарной артерии; диагностично-терапевтический алгоритм.

\section{THE DEVELOPMENT OF EXTENSIVE MYOCARDIAL INFARCTION DUE TO MULTIPLE CORONARY ARTERY ANEURYSMS}

\author{
@M. I. Shved, N. M. Kovbasa, N. I. Yarema, T. O. Dobrianskyi, \\ I. M. Herasymets, O. A. Prokopovych \\ I. Horbachevsky Ternopil National Medical University
}

SUMMARY. A wide range of fluctuations in the prevalence of aneurysmal coronary artery disease (from 0.02 to $1.4 \%$ ) is associated not only with the rarity of the pathology, but also with the non-specificity of clinical manifestations and the difficulties of visualization diagnostics.

The aim - analysis of modern approaches to diagnosis and treatment of patients with multiple coronary artery aneurysms complicated by acute myocardial infarction and analysis of our own clinical case to assess the adequacy of the proposed clinical diagnostic and treatment algorithm .

Material and Methods. Systemic analysis, bibliosemantics and case analysis of multiple coronary vessel aneurysms were used.

Results and Discussion. This clinical case is characterized by the typical clinical symptoms of acute coronary syndrome (ACS), which were caused by multiple coronary artery aneurysms. The etiology of ACS was identified using the method of contrasting coronary angiography. According to the proposed diagnostic and therapeutic algorithm for the management of such patients, the patient underwent coronary artery bypass grafting and prescribed dual antiplatelet and statin therapy, which gave a stable clinical effect.

Conclusions. The variety of clinical manifestations of aneurysmal heart disease determines the significant diagnostic difficulties of the disease and justifies the need to use of various diagnostic imaging approaches (coronary angiography, computerized tomography, aortography), and the direct tactics of treating patients with aneurysms/ectasia of the coronary arteries should be individualized on the basis of the proposed diagnostic and therapeutic algorithm.

KEY WORDS: coronary artery aneurysm; diagnostic-therapeutic algorithm. 